\title{
Are microbial communities in green roof substrates comparable to those in post-industrial sites?-a preliminary study
}

\author{
Chloe J. Molineux ${ }^{1,2}$ - Alan C. Gange ${ }^{1}$. \\ Stuart P. Connop ${ }^{2} \cdot$ Darryl J. Newport ${ }^{2}$
}

Published online: 27 March 2015

(C) Springer Science+Business Media New York 2015

\begin{abstract}
Green roofs have been implemented on new buildings as a tool to mitigate the loss of post-industrial or brownfield land. For this to be successful, the roofs must be designed appropriately; that is with the right growing media, suitable substrate depth, similar vegetation and with a comparable soil microbial community for a healthy rhizosphere. This study compared soil microbial communities (determined using phospholipid fatty acid or PLFA analysis) of two extensive green roofs and two post-industrial sites in Greater London. It was found that green roof rootzones constructed using engineered growing media are not depauperate, but can have an abundant soil microbial community that in some cases may be more diverse and numerous than communities found in brownfield areas. In this preliminary study, one green roof supported abundant soil microbial communities that were dominated by gram negative and aerobic bacteria, whilst fungal abundance was similar across all sites analysed. Furthermore, ratios of fungal: bacterial PLFA's were larger from postindustrial sites but overall were consistent with bacterial dominated soils typical of early successional habitats.
\end{abstract}

Keywords Brownfield $\cdot$ Biodiversity $\cdot$ Substrate $\cdot$ Growing media $\cdot$ PLFA $\cdot$ Microbes $\cdot$ Bacteria $\cdot$ Fungi

Chloe J. Molineux

chloe_molineux@yahoo.com

School of Biological Sciences, Royal Holloway University of London, Egham, Surrey TW20 0EX, UK

2 School of Architecture, Computing and Engineering, University of East London, Docklands Campus, 4-6 University Way, London, E16 2RD, UK 


\section{Introduction}

Extensive green roofs are becoming more and more popular in the U.K. Not only are these artificial habitats being created for economical and aesthetical purposes (Oberndorfer et al. 2007; Dunnett and Kingsbury 2008), they are also being used as a form of habitat relocation or reconciliation ecology (Brenneisen 2006; Oberndorfer et al. 2007; Francis and Lorimer 2011). With increasing amounts of post-industrial land or brownfield - extremely rich in flora and fauna (Gibson 1998) - being lost in the urban environment, green roofs are considered as a viable alternative; a compromise between city planners providing more housing and developments, and ecologists striving to maintain biodiversity (Wheater 1999; Jones 2003; Emilsson 2008; Schadek et al. 2009). For this reason, biodiversity roofs are often preferable, but tend to be overlooked for the more aesthetically pleasing Sedum blanket roofs, which allow for an instant green effect. The production of green roof substrates that are physically, chemically and biologically comparable to those of brownfield areas (Molineux et al. 2009) are desirable, as this should provide green roofs with the most favourable conditions for a diversity of wildflowers that are associated with urban wastelands. If the growing media is designed and engineered correctly, then these types of green roofs should be more attractive than they are at present because the plants should perform better in terms of growth, diversity and ecosystem services such as pollination provision (Molineux 2010).

There are very few studies on the microbial populations of green roofs, (Molineux 2010; McGuire et al. 2013; Molineux et al. 2014) yet these communities are fundamental to the health of the green roof ecosystem (Rumble and Gange 2013). It has been shown that wellestablished underground communities have huge benefits on the aboveground forbs and grasses, in early successional communities (Gange and Brown 2002; Wardle et al. 2004). If there is a viable microbial community then plant growth - and to some extent plant diversity (Gange et al. 1990; Van Der Heijden et al. 2006; Vogelsang et al. 2006) — should be increased. Molineux (2010) found that the inoculation of green roof substrates with either arbuscular mycorrhizal fungi (AMF) spores or with an addition of 'live' microbes in a compost tea could enhance the microbial biomass within substrate and subsequently produced plants that were larger with more foliage cover. However, the overall success of the inoculation experiments was that they needed only to be applied three times in 1 year for the effects to be sustained the following year (Molineux et al. 2014). Meanwhile, McGuire et al. (2013) examined the fungal communities of green roofs and parks in New York City, USA. They found that green roofs supported a distinct fungal composition compared to ground-level soils and that although these roof areas were small, all the major fungal phyla were found, suggesting good microbial diversity.

The microbial populations of post-industrial sites is again a topic of very few studies. Generally research has focused on the use of microbes in reclamation of contaminated land (Baniulyte et al. 2009), and how microbes could be used to reduce heavy metal concentrations; no literature could be found which describes the naturally occurring microbial communities of sites similar to brownfield land. There are studies from urban soils (Yuangen et al. 2006; Silva et al. 2010) and a few publications that have investigated the types of bacterial communities under pervious paving (Newman et al. 2002; Fan et al. 2014); yet despite this very little can be used from the literature for comparisons in this study. There do not seem to be any published studies that relate soil microbial biomass of brownfield land to the above-ground floral diversity, even though it is often reported that there is a strong synergy between the two. Microbes are important for soil nutrient recycling and overall ecosystem health and 
functioning, thus it is vital to know how green roofs compare to ground-level sites for links to then be made with above-ground biodiversity (Gange and Brown 2002). Many studies have shown positive effects on plant species diversity with the presence of a particular group of microorganisms - arbuscular mycorrhizal fungi or AMF (Grime et al. 1987; Gange et al. 1993; Klironomos et al. 2000). However, perhaps of most importance is the establishment of a common mycelial network through which nearby plants can exchange nutrients and even signals of herbivore attack (Van der Heijden et al. 1998; Babikova 2013). Thus, plant community structure and diversity are likely to be maximised at high levels of microbial diversity.

The aim of this preliminary study was to determine if soil microbial communities in green roofs are similar in abundance to the brownfield sites they are designed to mimic. It was a limited study with a low sample size due to difficulties with site access, however the overall objective was to describe the communities from each site and make general conclusions about the results, with the purpose of providing base-line data for a larger-scale experiments in the future. Given that the rootzone of green roofs is generally $80 \%$ substrate: $20 \%$ organic matter, it is naturally poor in resources for microbial growth. We therefore hypothesized that green roofs would support fewer microbes than post-industrial sites and that these communities would differ in composition.

\section{Materials and methods}

\section{Field sites}

\section{London Zoo gift shop green roof}

The London Zoo gift shop extensive green roof, Regent's Park, London $\left(51^{\circ} 32^{\prime} 10.0^{\prime \prime} \mathrm{N} 0^{\circ} 09^{\prime}\right.$ $\left.10.7^{\prime \prime} \mathrm{W}\right)$ was constructed in March 2005 with secondary recycled aggregate-including crushed red brick and crushed concrete mix - and covers a total of $180 \mathrm{~m}^{2}$. It was divided into $452 \mathrm{~m} \times 2 \mathrm{~m}$ plots, in the form of a grid-like structure incorporating three types of growing media at five different depths: substrate 1 is $25 \%$ crushed brick with $75 \%$ crushed concrete, substrate 2 is $50 \%$ crushed brick with $50 \%$ crushed concrete and substrate 3 is $75 \%$ crushed brick with $25 \%$ crushed concrete, with the depths at 3.5, 5.5, $5.5 \mathrm{~cm}$ with a water retention fleece and two with $8 \mathrm{~cm}$ depths. Organics, in the form of commercial topsoil, was applied over the entire roof (approx. $15 \%$ by volume) and all plots (except one block of $8 \mathrm{~cm}$ depths, which were left to colonise naturally) were seeded with a wildflower mix (from livingroofs.org). There has not been any maintenance of the roof vegetation since construction. All of the 15 substrate and depth treatment combinations were replicated three times to give 45 test plots in total. This experimental roof was a key site used for soil community analysis in Molineux (2010) and Molineux et al. (2014). In that study, microbial manipulations were performed in two of the depths $(5.5$ and $8 \mathrm{~cm})$ and two substrate types (substrate 1 and 3 ) in order to enhance the microbial abundance in green roof substrates. However for this manuscript, control plots (where no manipulations took place) in those same types and depths, were selected to provide an overview of the roof's microbial community for comparisons.

\section{Laban green roof}

The Laban extensive green roof is situated on the Laban dance centre in Deptford, London $\left(51^{\circ} 28^{\prime} 48.5^{\prime \prime} \mathrm{N} 0^{\circ} 01^{\prime} 08.6^{\prime \prime} \mathrm{W}\right)$. It was constructed in 2000 as a result of a planning condition 
stipulated in order for the centres' construction as it is in a site of nature conservation. It was designed with a crushed demolition waste substrate, which varies from 5 to $20 \mathrm{~cm}$ deep. It is approximately $450 \mathrm{~m}^{2}$ in size and was initially left to vegetate naturally. Over the first few years it became apparent that the vegetation was not flourishing and therefore a livingroof.org seed mix was applied to the substrate. In addition, wildflower seeds were collected locally from wasteland sites and seeded onto the roof. This has been carried out annually since 2002 . There has also been management of plant species considered as highly invasive i.e., Buddleia davidii (which was removed), however there was no additional fertilisation or water supplementation given.

\section{Sue Godfrey brownfield site}

The Sue Godfrey nature reserve, Deptford, London $\left(51^{\circ} 28^{\prime} 46.1^{\prime \prime} \mathrm{N} 0^{\circ} 01^{\prime} 17.9^{\prime \prime} \mathrm{W}\right)$, is a natural brownfield site that is 0.6 ha of mature and established wild flowers, typical of the low nutrient environment. This small area of wasteland was the site of an old pottery works (1682-1967) and a lorry park in recent times. It contains a rubble bank in the centre and a tribute to the pottery history with a small wall made from fragments of ceramics and mortar. It became a nature park in 1984 and was originally planted with trees and shrubs, with small paths running through it, but the rest was allowed to vegetate naturally. It is now known to have over 200 species of wild flowers, shrubs and trees. It is carefully managed to maintain this high species diversity with $50 \%$ of the grass cut each year (and trimmings removed to keep the nutrient level low), the trees and shrubs are also coppiced periodically allowing light to flood through to the flowering plants (www.lewisham.gov.uk). Thus this site was also sampled, to provide a comparison of a typical brownfield site with that of the roofs.

\section{Lytag site}

The Lytag site is the remnant of the old Lytag ${ }^{\circledR}$ factory in Tilbury, Essex $\left(51^{\circ} 27^{\prime} 36.6^{\prime \prime} \mathrm{N} 0^{\circ} 22^{\prime}\right.$ $52.0^{\prime \prime} \mathrm{E}$ ), which was relocated in 2005. This site is 12.4 ha of protected brownfield and lichen heath, which is home to a diversity of invertebrates, reptiles, birds, mammals and wasteland plants (Thurrock Council 2007; npower 2007). Lytag ${ }^{\circledR}$ is a lightweight secondary aggregate containing the waste material pulverised fuel ash, formed from electricity production in coalfired power stations (Lytag.net) and is similar in appearance/properties to clay pellets often used in green roof substrates. This site is therefore comprised of granular post-industrial waste, ash, clinker and rubble from old railway sidings; which has resulted in a free-draining, lownutrient acid grassland type soil. Management has only involved the removal of any encroaching scrub (Thurrock Council 2007).

\section{Soil/substrate samples}

\section{Collection}

Ten $100 \mathrm{~g}$ soil core samples of substrate were taken randomly from each of the chosen study sites in November 2007. Samples from the London Zoo roof were from the control plots only and here 12 samples were removed. Larger sample sizes were not possible, particularly from the green roofs, as permanent damage to the ecosystems may have occurred and there were also several issues with site access. Soil samples were taken from all sites in November (at the 
end of the growing season), so that seasonal variation in microbial biomass (Blume et al. 2002) was reduced as much as possible. This seasonality in soil microbial communities is said to be mainly due to changes in soil moisture (Van Gestel et al. 1992) and temperature (Papatheodorou et al. 2004). Work by Arnold et al. (1999) suggests that microbial biomass is increased under cool and wet conditions, thus November should have been an ideal soil sampling time.

\section{PLFA analysis}

All samples were put into individual sterile plastic freezer bags, labelled and stored at $-20{ }^{\circ} \mathrm{C}$ until analysed in December 2007. We used phospholipid fatty acid analysis, which is a process that extracts lipids from microbial cell walls and detects specific biomass indexes that can be related to a particular microbial group (Frostegård and Bååth 1996). The data output from the gas chromatograph following fatty acid extraction is in the form of peaks at specific signature biomarkers, which can subsequently be used to quantitatively analyse microbial communities within the soil samples (White and Ringelberg 1995). PLFA will determine up to 70 microbial peaks within a soil sample and is the type of analysis usually used to detect changes or shifts in microbial abundance: with different treatments, due to climate change, various substrate types and microbial manipulation experiments (Frostegård and Bååth 1996; Frostegård et al. 2011). Other methods for analysing microbial communities were considered, including; communitylevel physiological profiling (CLPP), PCR based methods such as denaturing gradient gel electrophoresis (DGGE), terminal restriction fragment length polymorphism (T-RFLP), ribosomal intergenic spacer analysis (RISA) and randomly amplified polymorphic DNA (RAPD) (Ramsey et al. 2006). However, PCR based methods are specific to genus or species level and can often be biased towards microbes which are more easily amplified and separate well on gel electrophoresis and therefore do not accurately represent overall biomass and CLPP techniques such as BIOLOG ${ }^{\circledR}$, effective for determining microbial growth on carbon substrates (matabolism), is also limited as only aerobic bacteria can be detected (Garland 1996; Smalla et al. 1998). Thus, PLFA was the most suitable methodology for microbial analysis for this study.

The PLFA procedure followed the methods described by Frostegård et al. (1991); in brief $0.50 \mathrm{~g}( \pm 0.02 \mathrm{~g})$ of soil/substrate from each plastic freezer bag was placed into large hexane rinsed tubes and fatty acids were extracted using $1.5 \mathrm{ml}$ citrate buffer, then $1.9 \mathrm{ml}$ chloroform, $3.75 \mathrm{ml}$ methanol and $2 \mathrm{ml}$ Bligh \& Dyer reagent. The supernatant was then filtered through solid phase extraction columns (Isolute ${ }^{\circledR}$ SI $500 \mathrm{mg}, 6 \mathrm{ml}$ capacity) to fractionate the lipids. The next stage was mild alkaline methanolysis using $1 \mathrm{ml}$ methanol/toluene (1:1), $1 \mathrm{ml} 0.2 \mathrm{M}$ potassium hydroxide, $2 \mathrm{ml}$ hexane/chloroform (4:1), $0.3 \mathrm{ml}$ acetic acid and $2 \mathrm{ml}$ Ultra-pure water resulting in an upper organic phase that was retained. Finally $200 \mu \mathrm{l}$ of internal standard (C19:0 nonadecanoic acid methyl ester) was added to the lipids and run through a 5890 Series II gas chromatographer (GC). The column used was SGE HT5 $25 \mathrm{~mm} \times 0.22 \mathrm{~mm}$ id $\times 0.1 \mu \mathrm{m}$ film thickness, with increasing temperature settings of 120 to $225^{\circ} \mathrm{C}$ at $2.5^{\circ} \mathrm{C}$ per minute, then rising to $325^{\circ} \mathrm{C}$ at $7.7^{\circ} \mathrm{C}$ per minute. Signature lipid biomarkers followed those described by Vestal and White (1989) for total bacterial PLFAs: C15:0i, C15:0ai, C15:0, C16:0i, C16:1 $\omega 7$, C17:0i, C17:0ai, C17:0cy, C17:0, C18:0br, these were also categorised into gram positive bacteria (C15:0i, C15:0ai, C16:0i, C17:0i, C17:0ai), gram negative bacteria (C17:0cy, $\mathrm{C} 18: 1 \omega 7, \mathrm{C} 19: 0 \mathrm{cy})$, aerobic bacteria $(\mathrm{C} 16: 1 \omega 7 \mathrm{c}, \mathrm{C} 18: 1 \omega 7)$ and anaerobic bacteria (C17:0cy, C19:0cy). Actinomycetes were identified as C18:0 (10Me) and fungal PLFAs as 


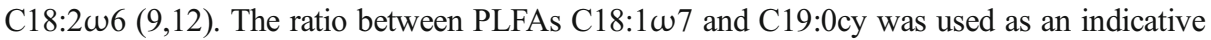
of environmental stress (Vestal and White 1989). The output from the GC at these peaks was used to determine the microbial biomass $(\mu \mathrm{g} / \mathrm{g})$ so that comparisons between sites could be made.

\section{Substrate properties}

The substrate samples were also used to calculate water holding capacity (\%), soil organic matter (\%) and $\mathrm{pH}$ values for each site. Water holding capacity was determined by soaking $30 \mathrm{~g}$ of each sample in distilled water for $48 \mathrm{~h}$ then surface blotted with paper towels before being weighed. After results were recorded, all samples were dried in an oven at $100{ }^{\circ} \mathrm{C}$ for at least $24 \mathrm{~h}$. After this time the aggregates were allowed to cool and then reweighed (as in BS 812-109:1990). The difference between the two weights was then converted to percentage water content. $\mathrm{pH}$ values were calculated by soaking $30 \mathrm{~g}$ of material in $75 \mathrm{ml}$ of distilled water for $24 \mathrm{~h}$, then three readings using a HANNA HI $4521 \mathrm{pH}$ meter were taken for each sample to get an accurate mean. Finally the organic content of the samples was calculated using loss on ignition (LOI). Dried samples (to $60^{\circ} \mathrm{C}$ ) of $10 \mathrm{~g}$ were weighed out into porcelain crucibles and placed in a muffle furnace at $500-550{ }^{\circ} \mathrm{C}$ for $24 \mathrm{~h}$. At these temperatures any organics are burnt off, thus only leaving inorganic materials behind. Once cooled samples were reweighed and LOI calculated. This percentage loss equates to the amount of soil organic matter (SOM) that was in the samples.

\section{Data analysis and statistics}

Differences in physical (water holding capacity) and chemical (pH values and soil organic matter) as well as biological (total bacteria, gram positive bacteria, gram negative bacteria, anaerobic bacteria, fungi, fungal/bacterial ratios and bacterial/fungal ratios) substrate properties were examined between sites with one-way analysis of variance (ANOVA) (Zar 2005). Means were separated with a Tukey's HSD post hoc test (Fowler et al. 1998). Data were tested for normality and transformed using log or square root when appropriate. For aerobic bacteria, aerobic/anaerobic bacteria ratios, actinomycetes and stress indicator PLFA's, data could not be normalised therefore Kruskall-Wallis tests were performed. Differences between means were determined using paired Mann-Whitney $U$ tests. All analyses were conducted using the statistical package SPSS v. 20.0.

We also employed non-metric multidimensional scaling analysis to examine differences in the microbial community composition across the different sites, using the CAP5 package (Pisces Conservation Ltd, Lymington, UK). ANOSIM was used to examine pairwise community differences.

\section{Results}

Total microbial biomass and that of individual groups varied between the sites (Table 1), The London Zoo roof plots were twice as abundant in total microbial PLFAs than the Sue Godfrey nature reserve and almost 4 times larger in biomass than the Lytag site; with the Laban roof being the least microbial rich site. When this is broken down into the proportional composition of specific microbial groups, we see that for all sites, bacterial PLFAs dominated (Fig. 1). 


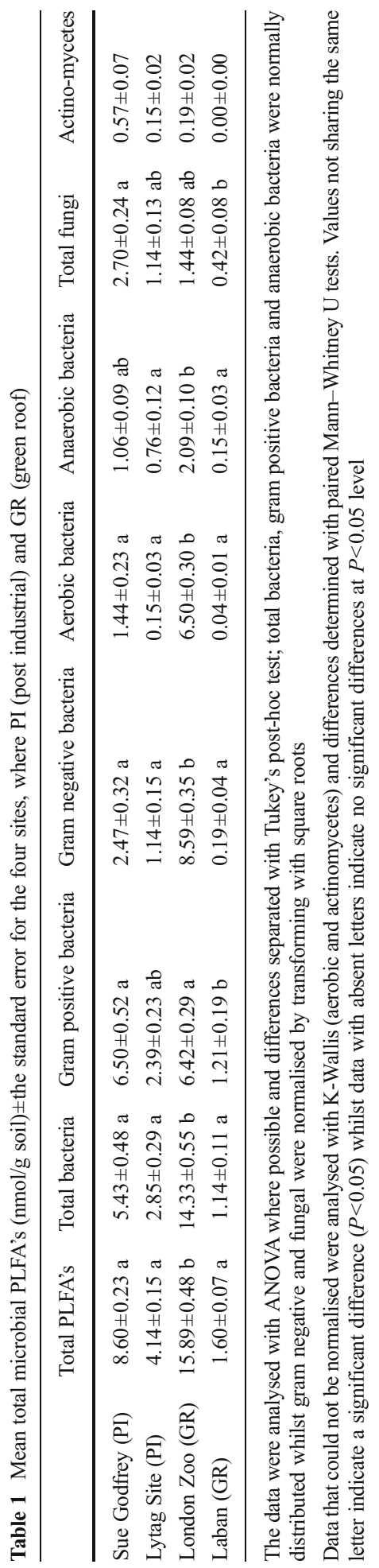




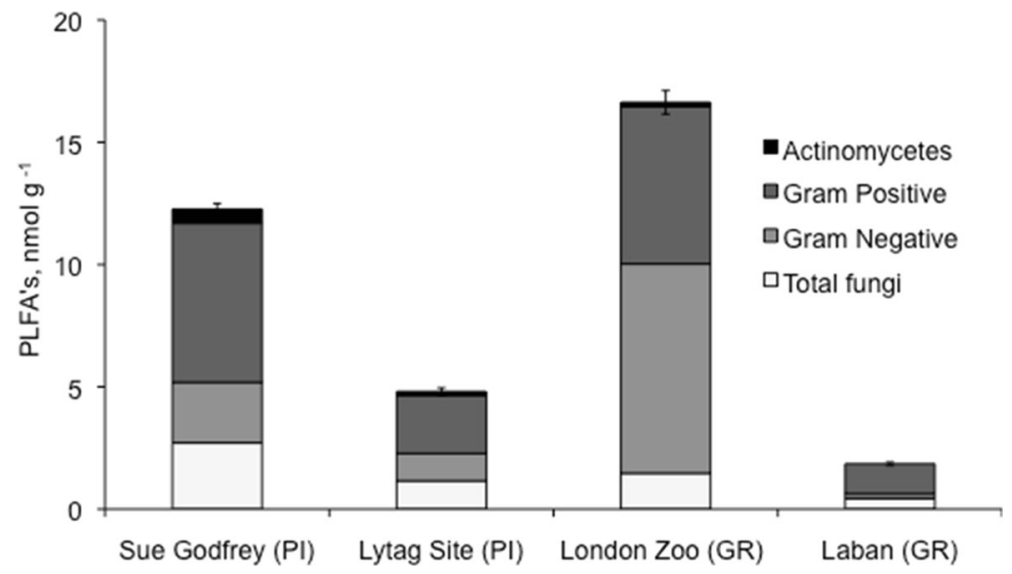

Fig. 1 Total microbial biomass (nmol/g soil) from two post-industrial $(P I)$ sites and two green roof $(G R)$ sites. Specific microbial groups proportioned to the bars, showing composition of microbial communities. Bars represent overall means \pm the standard error

Table 1 shows that London Zoo contained significantly higher levels of total bacteria $\left(\mathrm{F}_{3,38}=\right.$ 16.34, $P<0.001)$ and of this total, it also supported larger amounts of gram negative bacteria $\left(\mathrm{F}_{3,38}=22.97, P<0.001\right)$ and aerobic bacteria $\left(\chi^{2}=27.75\right.$, d.f $\left.=3, P<0.01\right)$. Meanwhile, anaerobic bacteria $\left(\mathrm{F}_{3,38}=5.79, P<0.01\right)$ and the gram positive bacteria $\left(\mathrm{F}_{3,38}=5.09, P<0.01\right)$ showed a different pattern in which the London Zoo roof differed only from Laban roof. Total fungal biomass was significantly different between the Sue Godfrey site and Laban $\left(\mathrm{F}_{3,38}=\right.$ $3.28, P<0.05)$ whilst actinomycete biomass did not differ between any of the sites.

Figure 2 shows the levels of stress indicative PLFAs, in which there was a significant difference between the sites $\left(\chi^{2}=16.05\right.$, d.f $\left.=3, P<0.001\right)$, with the Lytag post-industrial site being a more stressful environment than any other.

Figure 3 shows the differences between the fungal and bacterial biomass at each of the sites and the fungal:bacterial PLFA ratio. The fungal to bacterial ratio is used to determine the bacterial dominance in soil microbial communities. This was the lowest in samples from

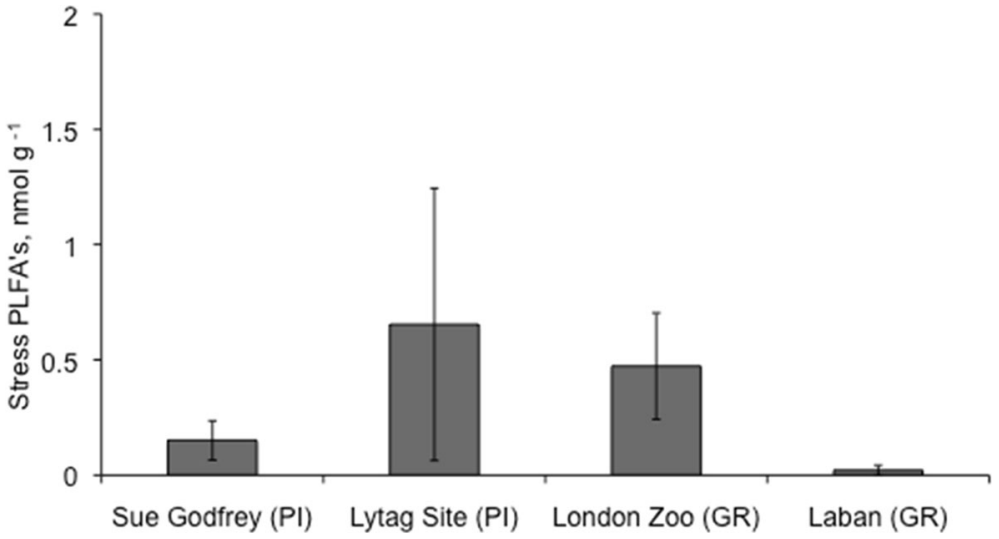

Fig. 2 Stress indicative PLFA's (ratio between C18:1 $\omega 7$ and C19:0cy), from two post-industrial $(P I)$ sites and two green roof $(G R)$ sites. Bars represent overall means \pm the standard error 


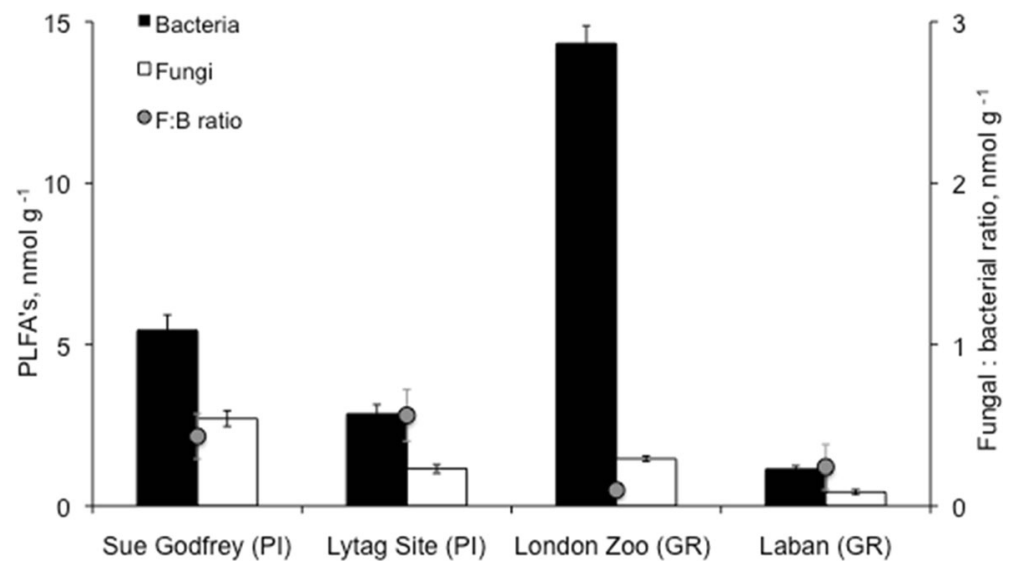

Fig. 3 Bacterial, fungal and the fungal:bacterial ratio PLFA's from two post-industrial $(P I)$ sites and two green roof $(G R)$ sites. Bars/points represent overall means \pm the standard error

London Zoo green roof and was significantly different to the other three sites $\left(\mathrm{F}_{3,38}=7.66\right.$, $P<0.001)$. However, Fig. 3 still indicates that all sites contains soils that are more bacterial than fungal dominated. Figure 4 shows the levels of aerobic bacteria, anaerobic bacteria and the ratio between them for each of the four sites. Results suggest that London Zoo is higher in this ratio of PLFA's $\left(\chi^{2}=28.76\right.$, d.f $\left.=3, P<0.001\right)$ than either the Laban roof or the postindustrial sites, this shows that samples from this site are aerobically dominated.

Table 2 shows the physical and chemical properties of the substrates that were sampled. The water holding capacity was significantly higher in plots on London zoo roof $\left(\mathrm{F}_{3,38}=43.90\right.$, $P<0.001)$ whilst the soil organic matter was larger in samples from the Sue Godfrey postindustrial site $\left(\mathrm{F}_{3,38}=22.71, P<0.001\right)$. The four sites ranged in $\mathrm{pH}$ between 7.4 and 8.1 , meaning that there were significant differences between them $\left(\mathrm{F}_{3,38}=7.42, P<0.001\right)$ with Laban roof being the most alkaline in nature.

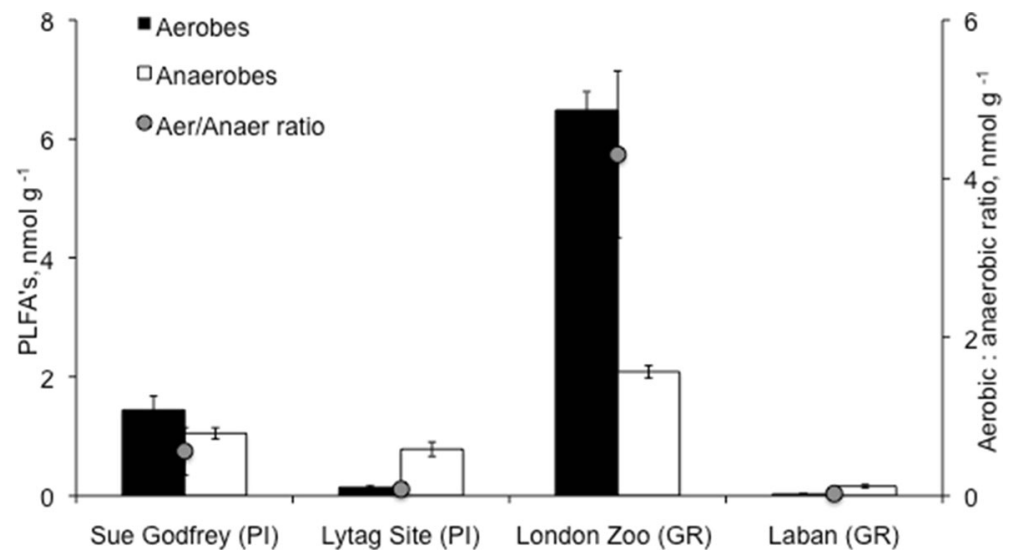

Fig. 4 Aerobic, anaerobic, and aerobic:anaerobic bacterial ratio PLFA's from two post-industrial $(P I)$ sites and two green roof $(G R)$ sites. Bars/points represent overall means \pm the standard error 
Table 2 Mean WHC (\%), SOM (\%) and pH Values \pm the standard error for substrate/soil samples from the four sites. The data were analysed with ANOVA and differences separated with Tukey's post-hoc test; values not sharing the same letter indicate a significant difference $(P<0.05)$

\begin{tabular}{llrl}
\hline & \% water holding capacity & \% soil organic matter & pH value \\
\hline Sue Godfrey (PI) & $10.61 \pm 1.70 \mathrm{a}$ & $18.14 \pm 1.83 \mathrm{a}$ & $7.77 \pm 0.08 \mathrm{ab}$ \\
Lytag Site (PI) & $13.76 \pm 2.16 \mathrm{a}$ & $7.55 \pm 0.92 \mathrm{~b}$ & $7.46 \pm 0.14 \mathrm{a}$ \\
London Zoo (GR) & $39.63 \pm 2.68 \mathrm{~b}$ & $10.63 \pm 1.47 \mathrm{~b}$ & $7.41 \pm 0.16 \mathrm{a}$ \\
Laban (GR) & $13.43 \pm 1.47 \mathrm{a}$ & $5.12 \pm 1.16 \mathrm{~b}$ & $8.13 \pm 0.06 \mathrm{~b}$ \\
\hline
\end{tabular}

The ordination analysis revealed a highly significant separation between the communities (Fig. 5) (ANOSIM, $r=0.493, P<0.001$ ). The Laban roof contained a different community structure to any of the other sites (Lytag: $P<0.05$; Sue Godfrey: $P<0.05$; London Zoo: $P<0.001$ ) as did the London Zoo roof (Lytag: $P<0.001$; Sue Godfrey: $P<0.001$ ). However, despite the differences in substrate composition, the structure of the microbial community was similar in the Lytag and Sue Godfrey sites. Furthermore, the ordination revealed a remarkable similarity between plots in the London Zoo roof, while communities within the other sites were considerably more variable, with the Lytag site being most variable (Fig. 5).

\section{Discussion}

This preliminary study has shown that green roofs have the potential to be the equal, or more abundant than brownfield/post-industrial sites in terms of soil microbial biomass, but that the structure of the communities within these substrates can differ. Previous work (Molineux 2010) suggested that green roofs were microbially depauperate; whilst this is supported by

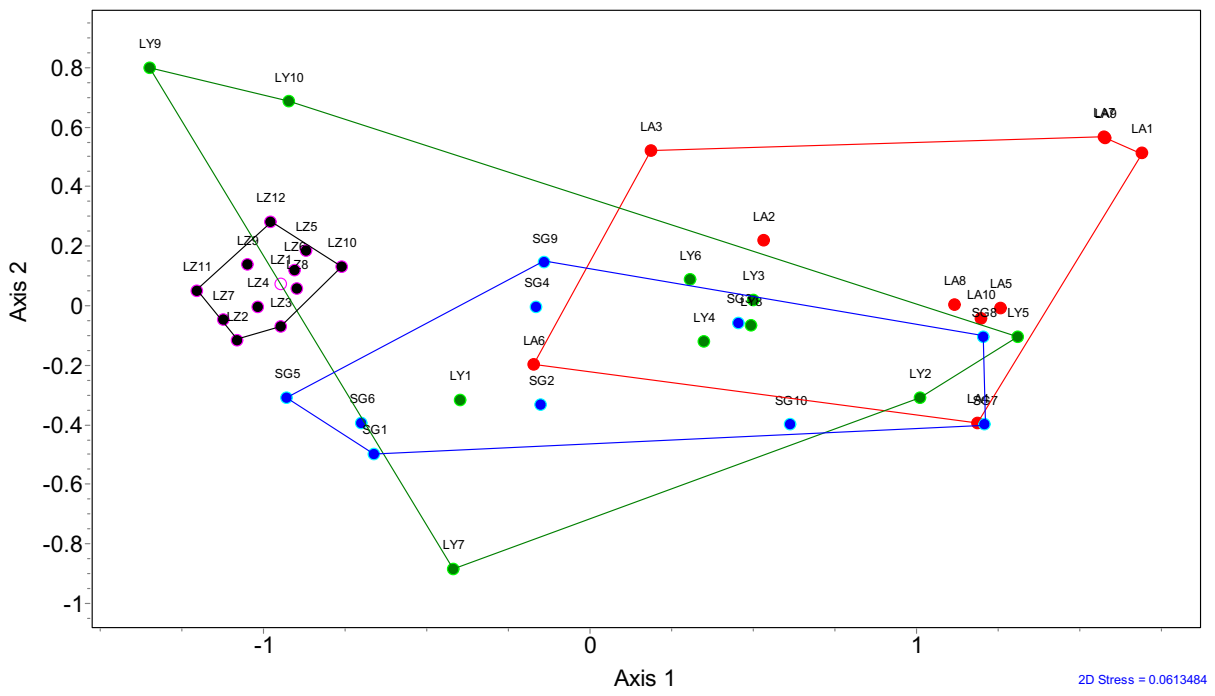

Fig. 5 Results of non-metric multidimensional scaling analysis of green roof and brownfield site soil microbial community structure. Key: LZ (black symbols): London Zoo green roof; LA (red symbols): Laban green roof; LY (green symbols): Lytag post-industrial site; SG (blue symbols): Sue Godfrey post-industrial site 
analysis of the Laban green roof in this study, we have also shown that in some case green roofs can support a soil microflora at levels similar to ground sites. For London Zoo green roof in particular the total microbial biomass was almost twice that of the Sue Godfrey brownfield site and comparable to levels recorded in other studies of bare or sparsely vegetated ground (Bardgett and Walker 2004; Yoshitake et al. 2006). Indeed, the levels were very similar to those found in early successional glaciers of high arctic regions in Canada (Hahn and Quideau 2013) and under revegetated crusts and sand dunes in the Tengger desert, China (Liu et al. 2013). It has been difficult to compare the findings to those of other urban habitats (Yuangen et al. 2006), however Silva et al. (2010) described higher levels of microbial fatty acids in roadside areas compared to those in ornamental city gardens. Yuangen et al. (2006), conversely, suggested that roadsides maybe more contaminated with heavy metals than other urban soil types and that this could account for the reduced microbial biomass and community structure in these areas.

The results of specific microbial groups were interesting with regards microbial community structure. There were no clear similarities between the two green roofs or between these and the two post-industrial sites; each seemed unique in the proportions of microbial groups it supported. London Zoo roof samples contained the biggest overall microbial biomass, which was largely comprised of bacterial communities; particularly aerobic bacteria and gram positive bacteria. Although this site did not contain the highest levels of soil organic matter, it did have the largest water holding capacity and perhaps this provided better conditions for increased microbial growth as described by Drenovsky et al. 2004 and Unger et al. 2009. It is also possible that these higher levels of microbial groups originated from the top soil that was applied to the roof during construction.

Aerobic, gram-positive and gram-negative bacteria were most abundant in London Zoo roof samples. Generally aerobic bacteria are associated with shallow soil depths (as are found on green roofs), whilst gram-positive bacteria are more abundant with decreasingly available $\mathrm{C}_{\text {org }}$ found in deeper rootzones (Fierer et al. 2003). Thus on London Zoo roof, the grampositive PLFAs may have been larger due to the green roof substrates having a higher water holding capacity (Drenovsky et al. 2004; Unger et al. 2009). Larger amounts of gram-negative bacterial PLFAs are however normally expected in shallower rootzones, as these microbes require a fresh input of organic carbon (Potthoff et al. 2006). However contradictory to this study, other authors suggest that gram-negative bacteria maybe more resilient to stress $(\mathrm{Wu}$ et al. 2014), particularly from land contamination/ pollutants (Zhang et al. 2008; Cycon et al. 2012) that are often associated with post-industrial areas like the Sue Godfrey brownfield site and the post-industrial Lytag site.

Increased proportions of aerobic bacterial PLFAs indicate substrates that are shallower in nature as anaerobic bacteria will increase with increasing soil depths. The ratio between these two types of bacteria also identifies soils dominated by aerobic bacteria (ratios $<1$ ) or anaerobic bacteria (ratios $>1$ ) ( $\mathrm{Li}$ et al. 2010). Indeed, Table 1 and Fig. 4 show how most sites in this study were aerobically dominated; with the Lytag post-industrial site being the only anaerobic bacteria dominated area. This composition of anaerobic dominance plus larger proportions of gram positive bacteria can occur if the site is prone to flooding events, as shown in studies by Bossio and Scow (1998) and Unger et al. (2009). This suggests that soil/ substrates in this habitat are not as free-draining and more compacted than those in other sites, resulting in less oxygen availability in the rhizosphere.

The stress indicative PLFA ratio between C18:1 $\omega 7$ and C19:0cy (Vestal and White 1989) supports this finding, showing the Lytag post-industrial site as more microbially stressed than 
the other sites tested. This pattern, if also found in larger-scale experiments, is positive in terms of the comparability of the roof level and the ground-level habitats. It was expected that the green roofs would suffer more than the post-industrial sites due to substrate depths (correlating to harsher conditions); yet the stress indicative ratio was lower from the two roofs in this study. Likewise, the levels of actinomycetes were similar in all sites. Actinomycetes are said to be most prominent in sub-surface depths as they are associated with a decrease in available organic carbon-like gram positive bacteria (Goodfellow and Williams 1983). Therefore they are also more abundant in anaerobic soils as they can utilise recalcitrant organic compounds (Potthoff et al. 2006). It was therefore expected that actinomycetes abundance would be greatest in the ground sites but again this was not the case in this investigation and the roof sites were not significantly different.

Fungal abundance differed between the Sue Godfrey site (containing the largest amount) and the Laban green roof (containing the least amount). Yet across the four sites, the range in levels were similar and comparable to those of other harsh terrains i.e., in deglaciated soils (Bardgett and Walker 2004) and desert ecosystems (Yoshitake et al. 2006). The relative proportions of fungi in relation to total microbial biomass were also similar (around $20 \%$ at all sites analysed) to work on urban soils by Silva et al. (2010). Although microbial data relating specifically to post-industrial land is lacking (Hartley et al. 2008) other studies have shown that fungi are less dependent on nutrient supply than other microbial groups and are also more drought-tolerant (Hackl et al. 2005), thus they should withstand conditions often found in the habitats studied here. The similarity in fungal abundance across the sites is an encouraging sign. Even though these sites differed greatly in substrate physical and chemical parameters, such as $\mathrm{pH}$, water holding capacity and nutrient availability (Table 2), these data do suggest that it is possible to establish similar levels of soil fungi in these habitats. It is highly likely that fungal species composition varies between the sites and an analysis of fungal species abundance in green roofs is the subject of our current research.

The ratios of fungal to bacterial PLFAs emphasised the pattern of bacterial dominated rootzones (ratios $<1$ ) in all four sites. For the Sue Godfrey nature reserve this ratio was the highest, whilst London Zoo green roof was the lowest and statistically different to all the other sites. This structure is what we would expect from areas with little organic carbon input (Hackl et al. 2005) and is characteristic of early successional habitats (Ohtonen et al. 1999; Tscherko et al. 2005; Hahn and Quideau 2013). Once the above-ground floral community has developed the soil fungal community increases, which subsequently supports higher trophic levels such as fungal feeding fauna (Moore and de Ruiter 2000). Fungi are said to be crucial for soil food web development (Smith et al. 2008) and therefore play a vital role in decomposition and nutrient recycling (Bardgett et al. 1999; Bardgett 2000). Brownfield sites are generally nutrient poor and therefore succession of these sites tends to be extremely slow; this is partly what makes them so interesting in terms of urban biodiversity. Most extensive green roofs (having limited substrate depths) provide conditions that will only ever support early successional plant species; therefore it is desirable to enhance their microbial communities (Molineux 2010; Molineux et al. 2014) to more fungal dominated ones in order to increase their biodiversity potential in the urban landscape.

The ordination analysis clearly showed distinct habitats with regards to microbial community structure, despite the limitations of this study this is a very interesting finding. London Zoo and Laban green roofs were different to the ground sites and from each other; yet within those sites (particularly at London Zoo) there was little variation in the microbial community. 
The ground sites contained similar microbial groups, however these sites were the most variable. This suggests that the microbial communities on green roofs may be highly specialised, as found in other extreme habitats (Hahn and Quideau 2013). Perhaps this is due to more diverse communities struggling to survive and establish at roof level. Further research to characterise microbial communities to a species level and determine their functionality within green roof ecosystems is needed and is an area of ongoing interest to us. Furthermore, work looking at the effect of building a mosaic of habitats on green roofs, to increase biodiversity - by using various substrates at different depths - may also increase the diversity of microbial groups to similar ranges as in ground-level sites, whilst maintaining that higher overall biomass (as found on roofs in this study).

A comparison of our findings to other published studies on urban soil microbial communities has been extremely difficult, with very limited examples in the literature. Work from Taiwan on communities below pervious pavements (Fan et al. 2014) have described the potential for increased diversity in an urban environment. Indeed, Silva et al. (2010) also suggest that roadside habitats can be more microbially abundant than ornamental gardens in cities. This work highlights the importance of post-industrial areas for a diversity of soil microbial groups and indicates that green roofs may support a more specialised range of species. This study is a preliminary insight into the microbial community structure of post-industrial sites and green roof habitats and as such it should be used for future developments in this research area and provide base-line data for further work.

\section{Conclusions}

Comparing microbial communities from only four different sites has been highly informative. By looking at post-industrial sites (including the Sue Godfrey nature reserve and the Lytag ${ }^{\circledR}$ site) the microbial communities on two green roofs can begin to be put into some relevance. In conclusion, this study has shown that green roof substrates are capable of being biologically comparable to those of biodiverse, post-industrial sites. Laban roof was disappointing in terms of total microbial biomass, yet for many of the specific microbial PLFA's it was similar to the two wasteland sites. In contrast, the London Zoo roof was the most abundant site for many of the microbial groups, suggesting that microbial populations can be sustainable in a roof substrate. We have shown that green roofs do not have sterile substrates, but ones that seem to be analogous to natural ecosystems; which could provide some resilience to the urban environment. It is important to recognise that engineered green roof growing media can support bacterial and fungal microorganisms; therefore the design of the substrate is vital for a healthy rhizosphere (Molineux 2010; Molineux et al. 2014). This below-ground community insight is encouraging for green roof ecology however more research is needed to determine if these microbes provide more favourable conditions for above-ground green roof flora and if there is a correlation with overall plant diversity.

Acknowledgments We are grateful to the Natural Environment Research Council (NERC) for funding this research, and to the EU FP7 project Transitioning towards Urban Resilience and Sustainability (TURAS) for post-analysis funding. Thanks also goes to Laban Dance Centre, Deptford (London) and ZSL London Zoo, Regent's Park (London) for access to the green roof sites. We would also like to thank our reviewers for their constructive comments and feedback. 


\section{References}

Arnold SS, Fernandez IJ, Rustad LE, Zibilske LM (1999) Microbial response of an acid forest soil to experimental soil warming. Biol Fertil Soils 30:239-44

Baniulyte D, Favila E, Kelly JJ (2009) Shifts in microbial community composition following surface application of dredged river sediments. Microb Ecol 57:160-169

Babikova Z, Gilbert L, Bruce TJA, Birkett M, Caulfield JC, Woodcock C, Pickett JA, Johnson D. (2013) Underground signals carried through common mycelial networks warn neighbouring plants of aphid attack. Ecol Letters 16:835-843

Bardgett RD (2000) Patterns of below-ground primary succession at Glacier Bay, south-east Alaska. Bull Br Ecol Soc 31:2

Bardgett RD, Walker LR (2004) Impact of coloniser plant species on the development of decomposer microbial communities following deglaciation. Soil Biol Biochem 36:555-559

Bardgett RD, Kandeler E, Tscherko D, Hobbs PJ, Jones TH, Thompson LJ, Bezemer TM (1999) Below-ground microbial community development in a high temperature world. Oikos 85:10

Blume E, Bischoff M, Reichert J, Moorman T, Konopka A, Turco R (2002) Surface and subsurface microbial biomass, community structure and metabolic activity as a function of soil depth and season. Appl Soil Ecol 592:12

Bossio DA, Scow KM (1998) Impacts of carbon and flooding on soil microbial communities: phospholipid fatty acid profiles and substrate utilization patterns. Microb Ecol 35:265-78

Brenneisen S (2006) Space for urban wildlife: designing green roofs as habitats in Switzerland. Urban Habitats 4:10

Thurrock Council (2007) Thurrock biodiversity study 2006-2011

Cycon M, Wojcik M, Borymski S, Piotrowska-Seget Z (2012) A broad-spectrum analysis of the effects of teflubenzuron exposure on the biochemical activities and microbial community structure of soil. J Environ Manag 108:27-35

Drenovsky RE, Elliott GN, Graham KJ, Scow KM (2004) Comparison of phospholipid fatty acid (PLFA) and total soil fatty acid methyl esters (TSFAME) for characterizing soil microbial communities. Soil Biol Biochem 36:1793-1800

Dunnett N, Kingsbury N (2008) Planting green roofs and living walls. Timber Press, Portland

Emilsson T (2008) Vegetation development on extensive vegetated green roofs: influence of substrate composition, establishment method and species mix. Ecol Eng 33:265-277

Fan L, Wang S, Chen C, Hsieh H, Chen J, Chen T, Chao W (2014) Microbial community structure and activity under various pervious pavements. J Environ Eng 140(3):04013012

Fierer N, Schimel JP, Holden PA (2003) Variations in microbial community composition through two soil depth profiles. Soil Biol Biochem 35:167-176

Fowler J, Cohen L, Jarvis P (1998) Practical statistics for field biology, 2nd edn. Wiley, Chichester

Francis RA, Lorimer J (2011) Urban reconciliation ecology: the potential of living roofs and walls. J Environ Manag 92:1429-1437

Frostegård A, Bååth E (1996) The use of phospholipid fatty acid analysis to estimate bacterial and fungal biomass in soil. Biol Fertil Soils 22:6

Frostegård A, Tunlid A, Bååth E (1991) Microbial biomass measured as total lipid phosphate in soils of different organic content. J Microbiol Methods 14:151-63

Frostegård Å, Tunlid A, Bååth E (2011) Use and misuse of PLFA measurements in soils. Soil Biol Biochem 43: 1621-1625

Gange AB, Brown VK (2002) Soil food web components affect plant community structure during early succession. Ecol Res 17:11

Gange A, Brown VK, Farmer LM (1990) A test of mycorrhizal benefit in an early successional plant community. New Phytol 115:7

Gange A, Brown VK, Sinclair GS (1993) Vesicular-arbuscular mycorrhizal fungi - a determinant of plant community structure in early succession. Funct Ecol 7:7

Garland JL (1996) Analytical approaches to the characterisation of samples of microbial communities using petterns of potential C source utilisation. Soil Biol Biochem 28:9

Gibson CWD (1998) Brownfield: red data. The values artificial habitats have for uncommon invertebrates. English Nature Research Report

Goodfellow M, Williams ST (1983) Ecology of actinomycetes. Annu Rev Microbiol 37:27

Grime JP, Mackey JML, Hillier SH, Read DJ (1987) Floristic diversity in a model system using experimental microcosms. Nature 328:3

Hackl E, Pfeffer M, Donat C, Bachmann G, Zechmeisterboltenstern S (2005) Composition of the microbial communities in the mineral soil under different types of natural forest. Soil Biol Biochem 37:661-671 
Hahn AS, Quideau SA (2013) Shifts in soil microbial community biomass and resource utilization along a Canadian glacier chronosequence. Can J Soil Sci 93:305-318

Hartley W, Uffindell L, Plumb A, Rawlinson HA, Putwain P, Dickinson NM (2008) Assessing biological indicators for remediated anthropogenic urban soils. Sci Total Environ 405:358-369

Jones R (2003) A celebration of urban entomology. Br J Entomol Nat Hist 16:12

Klironomos JN, McCune J, Hart M, Neville J (2000) The influence of arbuscular mycorrhizae on the relationship between plant diversity and productivity. Ecol Lett 3:137-141

Li M, Zhou Q, Tao M, Wang Y, Jiang L, Wu Z (2010) Comparative study of microbial community structure in different filter media of constructed wetland. J Environ Sci 22:127-133

Liu Y, Li X, Xing Z, Zhao X, Pan Y (2013) Responses of soil microbial biomass and community composition to biological soil crusts in the revegetated areas of the Tengger Desert. Appl Soil Ecol 65:52-59

McGuire KL, Payne SG, Palmer MI, Gillikin CM, Keefe D, Kim SJ, Gedallovich SM, Discenza J, Rangamannar R, Koshner JA, Massmann AL, Orazi G, Essene A, Leff JW, Fierer N (2013) Digging the New York City skyline: soil fungal communities in green roofs and city parks. PLoS ONE 8(3):e58020. doi:10.1371/journal. pone. 0058020

Molineux CJ (2010) Development of suitable growing media for effective green roofs. Royal Holloway University, Egham

Molineux CJ, Fentiman CH, Gange AC (2009) Characterising alternative recycled waste materials for use as green roof growing media in the U.K. Ecol Eng 35:1507-1513

Molineux CJ, Connop SP, Gange AC (2014) Manipulating soil microbial communities in extensive green roof substrates. Sci Total Environ 493:632-638

Moore JC, de Ruiter PC (2000) Invertebrates in detrital food webs along gradients of productivity. Cabi, New York

Newman AP, Pratt CJ, Coupe SJ, Cresswell N (2002) Oil bio-degradation in permeable pavements by microbial communities. Water Sci Technol 45(7):51-56

npower (2007) Environmental assessment scoping report: proposed new generation units at Tilbury power station

Oberndorfer E, Lundholm J, Bass B, Coffman RR, Doshi H, Dunnett N, Gaffin S, Köhler M, Liu KKY, Rowe B (2007) Green roofs as urban ecosystems: ecological structures, functions, and services. Bioscience 57:823-833

Ohtonen R, Fritze H, Pennanen T, Jumpponen A, Trappe J (1999) Ecosystem properties and microbial community changes in primary succession on a glacier forefront. Oecologia 119:239-246

Papatheodorou EM, Argyropouloub MD, Stamoua GP (2004) The effects of large- and small-scale differences in soil temperature and moisture on bacterial functional diversity and the community of bacterivorous nematodes. Appl Soil Ecol 24:13

Potthoff M, Steenwerth KL, Jackson LE, Drenovsky RE, Scow KM, Joergensen RG (2006) Soil microbial community composition as affected by restoration practices in California grassland. Soil Biol Biochem 38: $1851-1860$

Ramsey PW, Rillig MC, Feris KP, Holben WE, Gannon JE (2006) Choice of methods for soil microbial community analysis: PLFA maximizes power compared to CLPP and PCR-based approaches. Pedobiologia 20:6

Rumble H, Gange AC (2013) Soil microarthropod community dynamics in extensive green roofs. Ecol Eng 57: 197-204

Schadek U, Strauss B, Biedermann R, Kleyer M (2009) Plant species richness, vegetation structure and soil resources of urban brownfield sites linked to successional age. Urban Ecosyst 12:115-126

Silva L, Cachada A, Freitas AC, Pereira R, Rocha-Santos T, Duarte AC (2010) Assessment of fatty acid as a differentiator of usages of urban soils. Chemosphere 81:968-975

Smalla K, Wachtendorf U, Heuer H, Liu WT, Forney L (1998) Analysis of BIOLOG GN substrate utilization patterns by microbial communities. Appl Environ Microbiol 64:6

Smith RS, Shiel RS, Bardgett RD, Millward D, Corkhill P, Evans P, Quirk H, Hobbs PJ, Kometa ST (2008) Long-term change in vegetation and soil microbial communities during the phased restoration of traditional meadow grassland. J Appl Ecol 45:670-679

Tscherko D, Hammesfahr U, Zeltner G, Kandeler E, Bocker R (2005) Plant succession and rhizosphere microbial communities in a recently deglaciated alpine terrain. Basic Appl Ecol 6:16

Unger IM, Kennedy AC, Muzika R-M (2009) Flooding effects on soil microbial communities. Appl Soil Ecol 42:1-8

Van der Heijden MGA, Klironomos JN, Ursic M, Moutoglis P, Streitwolf-Engel R, Boller T (1998) Mycorrhizal fungal diversity determines plant biodiversity, ecosystem variability and productivity. Nature 396:72-75

Van Der Heijden MGA, Bakker R, Verwaal J, Scheublin TR, Rutten M, Van Logtestijn R, Staehelin C (2006) Symbiotic bacteria as a determinant of plant community structure and plant productivity in dune grassland. FEMS Microbiol Ecol 56:178-187

Van Gestel M, Ladd J, Amato M (1992) Microbial biomass responses to seasonal change and imposed drying regimes at increasing depths of undisturbed topsoil profiles. Soil Biol Biochem 24:9 
Vestal RJ, White DC (1989) Lipis analysis in microbial ecology: quantitative approaches to the study of microbial communities. Bioscience 39:6

Vogelsang KM, Reynolds HL, Bever JD (2006) Mycorrhizal fungal identity and richness determine the diversity and productivity of a tallgrass prairie system. New Phytol 172:554-562

Wardle DA, Bardgett RD, Klironomos JN, Setälä H, van der Putten WH, Wall DH (2004) Ecological linkages between aboveground and belowground biota. Science 11;304(5677):1629-1633

Wheater CP (1999) Urban habitats. Routledge, London

White DC, Ringelberg DB (1995) Utility of signature lipid biomarker analysis in determining in situ viable biomass, community structure, and nutritional physiological status of the deep subsurface microbiota. CRC Press, Boca Raton

Wu X, Xu J, Dong F, Liu X, Zheng Y (2014) Responses of soil microbial community to different concentration of fomesafen. J Hazard Mater 273C:155-164

Yoshitake S, Uchida M, Nakatsubo T, Kanda H (2006) Characterization of soil microflora on a successional glacier foreland in the high Arctic on Ellesmere Island, Nunavut, Canada using phospholipid fatty acid analysis. Polar Biosci 19:73-84

Yuangen Y, Campbell CD, Clark L, Cameron CM, Paterson E (2006) Microbial indicators of heavy metal contamination in urban and rural soils. Chemosphere 63:1942-1952

Zar JH (2005) Biostatistical analysis. Pearson Education, Upper Saddle River

Zhang Y, Zhang H, Li X, Su Z, Zhang C (2008) The cadA gene in cadmium-resistant bacteria from cadmiumpolluted soil in the Zhangshi Area of Northeast China. Curr Microbiol 56:236-239 